\title{
CORRELATION BETWEEN NUTRIENT CONTENT AND PRODUCTIVITY IN IRRIGATED FORAGES
}

\author{
CORRELAÇÃO ENTRE TEOR DE NUTRIENTES E PRODUTIVIDADE EM \\ FORRAGEIRAS IRRIGADAS
}

\author{
Carla Deisiane de Oliveira COSTA ${ }^{\mathbf{1}}$; Adriano da Silva LOPES ${ }^{\mathbf{~}}$, Marcos Jefferson KRAESKI ${ }^{\mathbf{1}}$; \\ Adriano de FRANÇA ${ }^{1}$; Alisson Rodrigo Almeida MARGATTO' \\ Eder Duarte FANAYA JÚNIOR ${ }^{1}$ \\ 1. State University of Mato Grosso do Sul, Aquidauana, MS, Brazil. carladeisiane@ hotmail.com
}

\begin{abstract}
Irregular rainfall can restrict crop development, so irrigation of pastures serves as a strategy to intensify grass-fed animal production systems. Due to the direct relationship between the availability of soil water and nutrients, the objective was to evaluate the nutrient content in forages irrigated by a central pivot system. This work was carried out in the experimental area of irrigated agriculture at the State University of Mato Grosso do Sul, in Aquidauana-MS, Brazil. The experiment was setup in a completely randomized design, with five replications, in subdivided plots. The treatments of the plots were irrigated and non-irrigated, and the treatments of the subplots were the forages Urochloa brizantha cv. Xaraes, Pennisetum purpureum cv. Napier, Panicum maximum cv. Mombasa and Urochloa ruziziensis cv. Ruziziensis. Foliar concentrations of the nutrients Nitrogen (N), Phosphorus (P), Potassium (K), Calcium (Ca), Magnesium (Mg), Sulfur (S), Boron (B), Copper $(\mathrm{Cu})$, Iron $(\mathrm{Fe})$, Manganese $(\mathrm{Mn})$ and Zinc $(\mathrm{Zn})$ were evaluated. Statistical analyses performed included analysis of variance, Tukey test at $p<0.05$ and linear correlation matrix at $p<0.05$ and $p<0.01$ between nutrients and productivity. Irrigation results in higher levels of the macronutrients $\mathrm{P}, \mathrm{K}$ and $\mathrm{Mg}$, and $\mathrm{Fe}$ and $\mathrm{Mn}$ micronutrients in forages. The nutrients that correlated with productivity were $\mathrm{P}$ and $\mathrm{Fe}$, which both presented negative correlation. The nutrients correlated better with each other than with forage productivity.
\end{abstract}

KEYWORDS: Irrigated pasture. Central pivot. Forage nutrition.

\section{INTRODUCTION}

Livestock production represents one of the most important sectors of the Brazilian economy. Its share of the agribusiness gross domestic product (GDP) in 2015 was $43 \%$, with the agribusiness GDP contributing to $21.35 \%$ of the national GDP (CEPEA, 2016).

According to the latest IBGE survey (2015), Brazil supports the largest commercial herd of cattle in the world, with more than 215 million head of cattle, which supply the domestic market and are also destined for export. According to the MAPA (2016), Brazil globally ranks first in beef exports.

Pastures represent the most economical method of feeding cattle, with a low cost of production in relation to confinements. Thus, according to Costa et al. (2010) the formation of good pasture is of great importance since it is the best option for feeding the cattle herd because it not only provides low-cost food, bus also offers all the necessary nutrients for good performance of the animals.

Irregularities of rainfall restrict the development of forage plants to the point that even during rainy seasons there are periods of water deficit, when evapotranspiration exceeds precipitation (ALENCAR et al., 2010).

Brazilian pastures are found in an advanced state of degradation, which results in a low stocking of animals per area. According to Mistura et al. (2006), the use of technologies and forage species with greater potential for production is essential to reverse this situation. The most commonly used forages, based on productive potential, are Pennisetum purpureum, Panicum maximum and Urochloa brizantha, and some of the technologies used include fertilization and irrigation.

Pasture irrigation serves as a strategy for the intensification of animal production systems, with the main objective of increasing the forage plant productivity so as to increase the support capacity of the pastures, and consequently increase the weight gain per unit area (KRAESKI, 2016).

Tropical forages present low macro and micronutrient contents where the mineral content is dependent on various factors. According to Alencar et al. (2010), the nutritional value of the forage varies throughout the year in irrigated versus nonirrigated areas. During some summer periods and 
predominantly in winter, there is a decrease in the nutritional value of the forages. Therefore water supplementation via irrigation is important because it changes the bromatological composition and quality of the plants.

Irrigation increases the productive potential of forage because it improves the availability of nutrients to be absorbed. According to Raij (2011), soil water is the carrier of chemical elements, nutrients and other substances to the roots, because when moving through the soil it carries in solution the nutrients that will be absorbed by the plant.

Therefore, it is important to study the effect of irrigation on nutrient availability in forages. This study aimed to evaluate the nutrient content and its correlation with productivity in forages irrigated by central pivot, in Aquidauana-MS, Brazil.

\section{MATERIAL AND METHODS}

The work was carried out in an experimental area of irrigated agriculture of the
State University of Mato Grosso do Sul Aquidauana Campus, with geographical coordinates $20^{\circ} 27^{\prime} 08^{\prime \prime}$ South latitude, 55 $40^{\prime} 15^{\prime \prime}$ West longitude and average elevation of 191 meters.

The regional climate according to the KÖPPEN classification is Aw, defined as subhumid warm tropical, with rainy season during the summer and dry winter, with average annual rainfall of $1200 \mathrm{~mm}$. The soil was classified as Dystrophic Red Ultisol (SCHIAVO et al., 2010).

The forages Panicum maximun cv. Mombasa, Urochloa ruziziensis cv. Ruziziensis and Urochloa brizantha cv. Xaraés were sown using 25 $\mathrm{kg} \mathrm{ha}^{-1}$ of pure seeds, while Pennisetum purpureum cv. Napier was propagated vegetatively, using $1 \mathrm{t}$ $\mathrm{ha}^{-1}$ at spacing of one meter between rows. Implantation was carried out on May 05, 2012 and the full emergency occurred 7 days after sowing both in the non-irrigated area and that irrigated by a central pivot.

In Figure 1 shows the climatic data observed during the experiment.

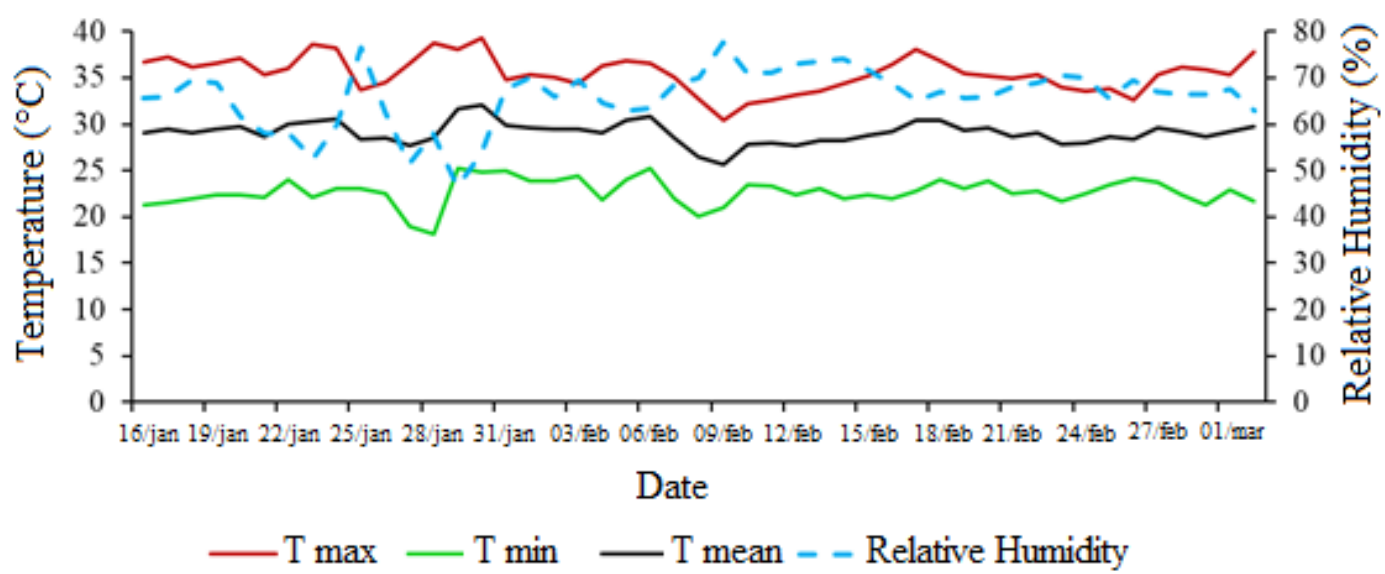

Figure 1. Relative humidity, maximum, minimum and mean temperature observed during the experiment, in Aquidauana-MS, Brazil.

The irrigation method employed utilized a center pivot of the FOCKINK $®$ brand, with $87.2 \%$ Christiansen Uniformity Coefficient (CUC) and 78.0\% Distribution Uniformity Coefficient (CUD) at $25 \%$ of the maximum speed of the center pivot (Figure 2).
The irrigated plot consisted of $8000 \mathrm{~m}^{2}$, where each forage occupied an area of $2000 \mathrm{~m}^{2}$ in the layout of pizza, with dimensions of $70 \mathrm{~m}$ (pivot radius) by $55 \mathrm{~m}$ width at the end. The non-irrigated forages totaled an area of $1170 \mathrm{~m}^{2}$, each occupying an area of $293 \mathrm{~m}^{2}$. 


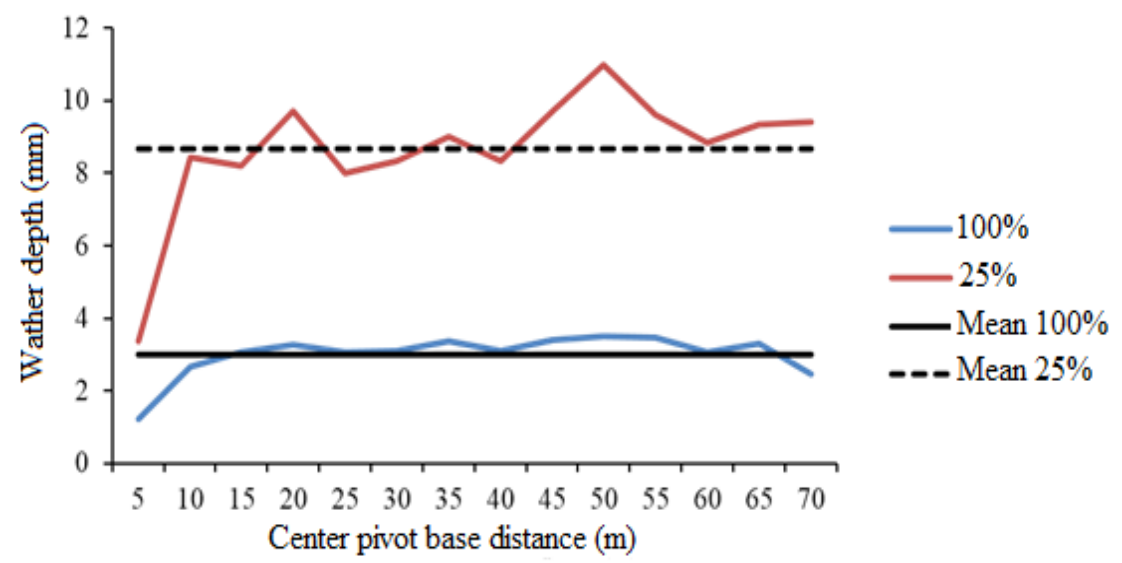

Figure 2. Mean water depths observed at $100 \%$ and $25 \%$ of the maximum speed of central pivot in Aquidauana-MS, Brazil.

Irrigation management began on the forage emergence date, using the daily reference evapotranspiration estimate (ETo) based on the Penman-Monteith method (Equation 1) (ALLEN et al., 1998), considering $50 \%$ of the soil available water capacity (AW) as soil water depletion factor (BERNARDO et al., 2007). The values for the effective root zone $(\mathrm{Z})$ and the crop coefficient $(\mathrm{Kc})$ were $0.4 \mathrm{~m}$ and 1.05 , respectively.

$\mathrm{ETo}_{(\mathrm{PM})}=\frac{0,408 \Delta(\mathrm{Rn}-\mathrm{G})+\gamma\left(\frac{900 \mathrm{U}_{2}}{\mathrm{~T}_{\text {med }}+273}\right)(\mathrm{es}-\mathrm{ea})}{\Delta+\gamma\left(1+0,34 \mathrm{U}_{2}\right)}$

Where, $\mathrm{ETo}_{(\mathrm{PM})}$ is the reference evapotranspiration by the Penman-Monteith method, $\mathrm{mm} \mathrm{d}^{-1} ; \Delta$ is the steam saturation curve declination water, $\mathrm{kPa}{ }^{\circ} \mathrm{C}^{-1} ; \mathrm{Rn}$ is the radiation balance, MJ $\mathrm{m}^{-2} \mathrm{~d}^{-1} ; \mathrm{G}$ is the heat flow in the soil, MJ $\mathrm{m}^{-2} \mathrm{~d}^{-1} ; \gamma$ is the psychrometric constant $(0.0659823) ; \mathrm{u}_{2}$ is the average wind speed at $2 \mathrm{~m}$ above the soil surface, $\mathrm{m} \mathrm{s}^{-1} ; \mathrm{T}_{\text {méd }}$ is the average air temperature, ${ }^{\circ} \mathrm{C}$; es is the vapor saturation pressure, $\mathrm{kPa}$; and ea is the current vapor pressure, $\mathrm{kPa}$.

During the experimental period, ten rain events occurred totaling $167 \mathrm{~mm}$, thus only three irrigations were necessary, which together totaled $62.7 \mathrm{~mm}$. The first was at the beginning of regrowth in January and two in February, one at the beginning and other at the end of the month, maintaining the soil water level within the appropriate range (Figure $3)$.

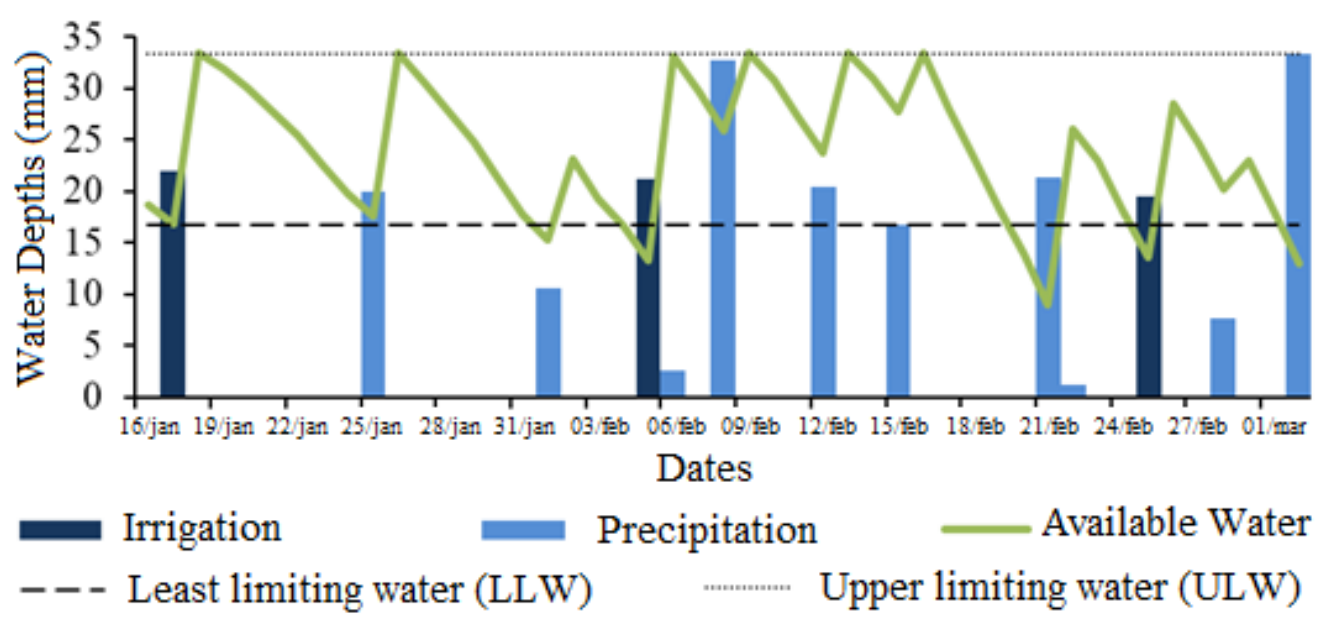

Figure 3. Precipitation and irrigation volumes registered in the area during the experiment, in Aquidauana-MS, Brazil.

Fertilization of the plants was carried out according to soil chemical analysis (Table 1) in agreement with Sousa and Lobato (2004). Coverage fertilization was carried out at the beginning of growth, applying $100 \mathrm{~kg} \mathrm{ha}^{-1}$ of nitrogen in the form of urea. 
Table 1. Soil chemical analysis of the experimental area for irrigated and non-irrigated forages, in the city of Aquidauana - MS, Brazil.

\begin{tabular}{|c|c|c|c|c|c|c|c|c|c|c|}
\hline $\begin{array}{c}\mathrm{pH} \\
\mathrm{H}_{2} \mathrm{O}\end{array}$ & $\begin{array}{c}\mathrm{P} \\
\mathrm{mg} \mathrm{dm}^{-3}\end{array}$ & $\begin{array}{c}\mathrm{OM} \\
\mathrm{g} \mathrm{dm}^{-3}\end{array}$ & K & $\mathrm{Ca}$ & $\begin{array}{l}\mathrm{Mg} \\
\mathrm{mol} \mathrm{c}\end{array}$ & $\mathrm{Al}$ & $\mathrm{H}$ & $\mathrm{BS}$ & CEC & $\begin{array}{l}\mathrm{V} \\
\%\end{array}$ \\
\hline \multicolumn{11}{|c|}{ Irrigated Area } \\
\hline 5.4 & 45.8 & 20.3 & 0.2 & 3.6 & 0.9 & 0.2 & 3.5 & 4.7 & 8.3 & 55.9 \\
\hline \multicolumn{11}{|c|}{ Non Irrigated Area } \\
\hline 5.2 & 41.3 & 19.7 & 0.2 & 1.6 & 0.5 & 0.0 & 2.8 & 2.3 & 5.1 & 45.1 \\
\hline
\end{tabular}

$\mathrm{P}$ - Phosphorus via the Mehlich Extractor, OM - Organic Matter, BS - Base Sum, CEC - Cation Exchange Capacity, V - Base Saturation.

The experimental design was completely randomized, with five replications, in subdivided plots. Statistical analyses performed included: analysis of variance, Tukey's test at $p<0.05$ and the linear correlation matrix at $\mathrm{p}<0.05$ and $\mathrm{p}<0.01$ between the nutrients and productivity.

The treatments of the plots were irrigated and non-irrigated, and the treatments of the subplots were the forages Urochloa brizantha cv. Xaraés, Pennisetum purpureum cv. Napier, Pannicum maximum cv. Mombasa and Urochloa ruziziensis cv. Ruziziensis.

Sampling was carried out during the regrowth period adopted for 45 days. Evaluations were made 15 days after the start of the season, where a homogenization cut was performed at the height of $30 \mathrm{~cm}$ for the napier, mombasa and xaraés forages, and $25 \mathrm{~cm}$ for the ruziziensis forage on January 16, 2013, with harvest on March 2 of the same year.

An iron frame measuring $0.25 \mathrm{~m}^{2}$ in area $(50 \mathrm{~cm} \times 50 \mathrm{~cm})$ was used, randomly thrown into the plot, and the forage was cut with a manual swather at a height of $15 \mathrm{~cm}$ from the ground.

After cutting, the harvested material was separated into leaves and stems which were weighed to obtain the total green mass (TGM), these were subsequently packaged in paper bags and pre-dried in an oven with forced air ventilation at $65{ }^{\circ} \mathrm{C}$ for 72 hours to determine the total dry mass (TDM).

The dry mass accumulation rate (DMAR) was determined from the dry mass productivity $(\mathrm{kg}$ $\mathrm{ha}^{-1}$ ) and cutting period (days), via Equation 2.

$\mathrm{DMAR}=\frac{\text { Prod }_{\mathrm{ms}}}{\text { Interval }}$

Where DMAR is the dry mass accumulation rate, $\mathrm{kg}$ $\mathrm{ha}^{-1} \mathrm{dia}^{-1} ; \operatorname{Prod}_{\mathrm{ms}}$ is the dry mass productivity, $\mathrm{kg} \mathrm{ha}$ ${ }^{1}$; and Interval is the cutting period in days.
The aerial part was milled and passed through a $1 \mathrm{~mm}$ sieve for subsequent laboratory analysis to determine the levels of the macronutrients $\mathrm{N}, \mathrm{P}, \mathrm{K}, \mathrm{Ca}, \mathrm{Mg}$ and $\mathrm{S}$ and micronutrients $\mathrm{B}, \mathrm{Cu}, \mathrm{Fe}, \mathrm{Mn}$ and $\mathrm{Zn}$, according to the methodology proposed by Malavolta et al. (1997).

\section{RESULTS AND DISCUSSION}

Irrigation resulted in higher forage productivity, with observed increases of $41.34 \%$ for TGM and $40.68 \%$ for TDM and DMAR in the irrigated treatment, where Napier was the most productive forage (Table 2). However, it should be noted that this work was carried out in the summer period, during which time it is common to observe smaller increments in productivity in relation to the other times of the year because it is the rainy season (Figure 3).

Other authors also observed increases in productivity of irrigated forages, including Ribeiro et al. (2009) and Aveiro et al. (1991). Ribeiro et al. (2009) observed increases in the availability of TDM for Napier and Mombasa forages of 23 and $48 \%$ in the dry season, and 15 and $29 \%$ in the rainy season, respectively. Aveiro et al. (1991) observed a $42 \%$ increase in TGM in the spring, summer and autumn periods, agreeing with the results obtained in the present work. It was observed that even in the summer irrigation resulted in higher productivity for the studied forages, which shows its importance to increase production even during rainy periods.

The highest levels of the macronutrients $\mathrm{P}$, $\mathrm{K}$ and $\mathrm{Mg}$ were found in the irrigated treatment. It is observed that the different forages had an effect on the macronutrients contents $\mathrm{N}, \mathrm{P}, \mathrm{K}$ and $\mathrm{Ca}$ (Table 3). According to Pires et al. (2006), the nutrient levels in the plants are directly related to the forage and the level of management established. 
Table 2. Productivity of different forages, Coefficient of Variation (CV) and least significant difference (LSD).

\begin{tabular}{|c|c|c|c|}
\hline Treatments & TGM & TDM & DMAR \\
\hline & ----- r r n & - $\mathrm{kgha}^{-1}$ & ---. \\
\hline Irrigated & $52054.96 \mathrm{~A}$ & $16224.28 \mathrm{~A}$ & $360.54 \mathrm{~A}$ \\
\hline Non irrigated & $21517.96 \mathrm{~B}$ & $6599.46 \quad \mathrm{~B}$ & $146.65 \mathrm{~B}$ \\
\hline Forages & ------------------------ & -------------------------- & --------------------------- \\
\hline Napier & $85919.76 \mathrm{a}$ & $32857.80 \mathrm{a}$ & $730.17 \mathrm{a}$ \\
\hline Mombasa & $27339.96 \mathrm{~b}$ & 5374.52 b & $119.43 \mathrm{~b}$ \\
\hline Xaraés & $18215.44 \mathrm{~b}$ & $4235.44 \quad \mathrm{~b}$ & $94.12 \mathrm{~b}$ \\
\hline Ruziziensis & $15669.24 \mathrm{~b}$ & $3179.72 \mathrm{~b}$ & $70.66 \mathrm{~b}$ \\
\hline $\mathrm{CV}(\%)$ & 43.80 & 41.09 & 41.09 \\
\hline \multicolumn{4}{|c|}{ LSD } \\
\hline Irrigation & 14146.68 & 4117.20 & 91.49 \\
\hline Forage & 29326.14 & 8534.99 & 189.67 \\
\hline
\end{tabular}

Total green mass (TGM), total dry matter (TDM) and dry mass accumulation rate (DMAR). Averages followed by equal letters in the column, uppercase and lowercase in the plot and subplot, respectively, do not statistically differ from each other by the Tukey test $\mathrm{p}$ $<0.05$.

Table 3. Macronutrient contents in leaves of different forages, Coefficient of Variation (CV) and least significant difference (LSD).

\begin{tabular}{|c|c|c|c|c|c|c|}
\hline Treatments & $\mathbf{N}$ & $\mathbf{P}$ & $\bar{K}$ & $\mathbf{C a}$ & Mg & $\mathbf{S}$ \\
\hline Irrigated & $18.15 \mathrm{~A}$ & $3.98 \mathrm{~A}$ & $20.13 \mathrm{~A}$ & $3.95 \mathrm{~A}$ & $2.05 \mathrm{~A}$ & $1.35 \mathrm{~A}$ \\
\hline Non irrigated & $18.14 \mathrm{~A}$ & $3.29 \mathrm{~B}$ & $17.91 \mathrm{~B}$ & $4.29 \mathrm{~A}$ & $1.77 \mathrm{~B}$ & $1.31 \mathrm{~A}$ \\
\hline Forages & ----------- & ---------- & ----------- & ----------- & ------------ & ----------- \\
\hline Napier & $20.41 \mathrm{a}$ & $3.98 \mathrm{a}$ & $22.50 \mathrm{a}$ & $4.98 \mathrm{a}$ & $1.85 \mathrm{a}$ & $1.52 \mathrm{a}$ \\
\hline Mombasa & $16.06 \mathrm{~b}$ & $3.68 \mathrm{a}$ & $19.25 \mathrm{ab}$ & $4.02 \mathrm{ab}$ & $2.00 \mathrm{a}$ & $1.17 \mathrm{a}$ \\
\hline Xaraés & $17.99 \mathrm{ab}$ & $2.92 \mathrm{~b}$ & $17.06 \mathrm{~b}$ & $3.87 \mathrm{ab}$ & $1.83 \mathrm{a}$ & $1.20 \mathrm{a}$ \\
\hline Ruziziensis & $18.10 \mathrm{ab}$ & $3.95 \mathrm{a}$ & $17.25 \mathrm{~b}$ & $3.61 \mathrm{~b}$ & $1.94 \mathrm{a}$ & $1.42 \mathrm{a}$ \\
\hline CV (\%) & 13.75 & 11.40 & 17.20 & 23.15 & 14.03 & 22.47 \\
\hline \multicolumn{7}{|c|}{ LSD } \\
\hline Irrigation & 1.61 & 0.27 & 2.11 & 0.61 & 0.17 & 0.19 \\
\hline Forage & 3.02 & 0.50 & 3.96 & 1.15 & 0.32 & 0.36 \\
\hline
\end{tabular}

Averages followed by equal letters in the column, uppercase and lowercase, in the plot and subplot, respectively, do not statistically differ from each other by the Tukey test $\mathrm{p}<0.05$.

Higher levels were observed for $\mathrm{N}$ and $\mathrm{K}$, independent of the treatment and forage. According to Costa et al. (2010), in forage production systems the nutrients nitrogen and potassium are those the most extracted by forage, in agreement with the results obtained in this work.

According to Embrapa (2001), for the forages studied the results found are in the acceptable ranges. The only exception was for $\mathrm{P}$, which is above the appropriate range. This probably occurred due to the high content of this nutrient in the soil, which according to Raij et al. (2001) is between 31 and $60 \mathrm{mg} \mathrm{dm}^{-3}$ (Table 1).

Contents of the micronutrients $\mathrm{Mn}$ and $\mathrm{Fe}$ were higher in the irrigated areas (Table 4). According to Lopes (1999), soil water content affects the availability of Mn. Therefore, the author reported that because the micronutrients $\mathrm{Cu}, \mathrm{Fe}$ and
Mn are metals they are often in imbalance, so the greater availability of $\mathrm{Fe}$ and $\mathrm{Mn}$ may have reduced the absorption of $\mathrm{Cu}$ by the plant.

There was no effect of irrigation and different forages on the contents of the micronutrients $\mathrm{B}, \mathrm{Cu}$ and $\mathrm{Zn}$ (Table 4). Oliveira et al. (2006) reported that other factors influence the availability of micronutrients for plants, such as texture, organic matter and especially the soil $\mathrm{pH}$.

In relation to $\mathrm{Fe}$ and $\mathrm{Mn}$, their contents were also influenced by forage, where the highest results of Fe were for Napier, and Mn for Mombasa. Regarding the extraction of micronutrients, it is observed that $\mathrm{Fe}$ and $\mathrm{Mn}$ were the micronutrients most absorbed by the forages studied. Pott et al. (1989) also observed higher levels of $\mathrm{Fe}$ and $\mathrm{Mn}$ in tropical forages. According to Malavolta (2006), Fe 
is the first and $\mathrm{Mn}$ the second most absorbed

micronutrient by plants.

Table 4. Micronutrient contents in leaves of different forages, Coefficient of Variation (CV) and least significant difference (LSD).

\begin{tabular}{|c|c|c|c|c|c|}
\hline Treatments & B & $\mathbf{C u}$ & $\mathbf{F e}$ & Mn & $\mathbf{Z n}$ \\
\hline Irrigated & $11.00 \mathrm{~A}$ & $36.30 \mathrm{~A}$ & $101.35 \mathrm{~A}$ & $86.80 \mathrm{~A}$ & $26.20 \mathrm{~A}$ \\
\hline Non irrigated & $11.58 \mathrm{~A}$ & $33.19 \mathrm{~A}$ & $77.53 \quad \mathrm{~B}$ & $65.23 \quad \mathrm{~B}$ & $25.63 \mathrm{~A}$ \\
\hline Forages & -------------- & -------------- & -------------- & -------------- & ------------ \\
\hline Napier & $9.70 \mathrm{a}$ & $40.50 \mathrm{a}$ & $111.50 \mathrm{a}$ & $68.20 \quad b$ & $35.20 \mathrm{a}$ \\
\hline Mombasa & $12.00 \mathrm{a}$ & $38.10 \mathrm{a}$ & $78.40 \mathrm{~b}$ & $98.40 \mathrm{a}$ & $25.00 \mathrm{a}$ \\
\hline Xaraés & $11.85 \mathrm{a}$ & $35.38 \mathrm{a}$ & $84.25 \mathrm{~b}$ & $72.95 \mathrm{~b}$ & $20.75 \mathrm{a}$ \\
\hline Ruziziensis & $11.60 \mathrm{a}$ & $25.00 \mathrm{a}$ & $83.60 \mathrm{~b}$ & $64.50 \quad b$ & $22.70 \mathrm{a}$ \\
\hline $\mathrm{CV}(\%)$ & 26.31 & 39.88 & 19.69 & 19.08 & 62.18 \\
\hline \multicolumn{6}{|c|}{ LSD } \\
\hline Irrigation & 1.91 & 8.92 & 11.34 & 9.34 & 10.38 \\
\hline Forage & 3.60 & 16.79 & 21.33 & 17.57 & 19.52 \\
\hline
\end{tabular}

Averages followed by equal letters in the column, uppercase and lowercase, in the plot and subplot, respectively, do not differ statistically from each other by the Tukey test $\mathrm{p}<0.05$.

According to Embrapa (2001), independent of the treatment the contents of $\mathrm{B}, \mathrm{Cu}$ and $\mathrm{Zn}$ were close to the adequate range, while the $\mathrm{Fe}$ and $\mathrm{Mn}$ contents were higher than expected, even though these micronutrients had not been applied. Although they were not applied, the micronutrient levels are within the appropriate range and above it, and this can be attributed to the existence of these elements in the local soil, from fertilization of previous crops or due to the soil source material.
Different correlations were observed between the studied forages. There was a negative correlation $(p<0.05)$ between P and TGM for the Napier forage, which was the only significant correlation observed for the macronutrients (Table 5). This negative correlation may be due to the high levels of $\mathrm{P}$ in the soil (Table 1) and in the plant (Table 3).

Table 5. Simple linear correlation matrix between macronutrients ( $, \mathrm{P}, \mathrm{K}, \mathrm{Ca}, \mathrm{Mg}$ and $\mathrm{S}$ ) and total green mass (TGM), total dry matter (TDM) and dry mass accumulation rate (DMAR) for irrigated forages.

\begin{tabular}{|c|c|c|c|c|c|c|}
\hline \multicolumn{7}{|c|}{ Napier } \\
\hline & $\mathbf{N}$ & $\mathbf{P}$ & $\mathbf{K}$ & $\mathbf{C a}$ & Mg & $\mathbf{S}$ \\
\hline TGM & 0.060 & $-0.909 *$ & 0.128 & 0.589 & -0.087 & -0.312 \\
\hline TDM & 0.664 & -0.851 & -0.473 & 0.698 & 0.563 & 0.063 \\
\hline DMAR & 0.664 & -0.851 & -0.473 & 0.698 & 0.563 & 0.063 \\
\hline \multicolumn{7}{|c|}{ Mombasa } \\
\hline & $\mathbf{N}$ & $\mathbf{P}$ & $\mathbf{K}$ & $\mathbf{C a}$ & Mg & $\mathbf{S}$ \\
\hline TGM & 0.080 & 0.166 & -0.676 & -0.631 & -0.399 & 0.491 \\
\hline TDM & 0.505 & 0.489 & -0.711 & -0.753 & -0.660 & 0.523 \\
\hline DMAR & 0.505 & 0.489 & -0.711 & -0.753 & -0.660 & 0.523 \\
\hline \multicolumn{7}{|c|}{ Xaraés } \\
\hline & $\mathbf{N}$ & $\mathbf{P}$ & $\mathbf{K}$ & $\mathbf{C a}$ & Mg & $\mathbf{S}$ \\
\hline TGM & 0.219 & -0.713 & -0.093 & -0.393 & -0.189 & 0.123 \\
\hline TDM & 0.366 & -0.687 & -0.176 & -0.340 & -0.223 & 0.105 \\
\hline DMAR & 0.366 & -0.687 & -0.176 & -0.340 & -0.223 & 0.105 \\
\hline \multicolumn{7}{|c|}{ Ruziziensis } \\
\hline & $\mathbf{N}$ & $\mathbf{P}$ & $\mathbf{K}$ & $\mathrm{Ca}$ & Mg & $\mathbf{S}$ \\
\hline TGM & 0.438 & 0.267 & 0.634 & -0.067 & -0.363 & -0.294 \\
\hline TDM & 0.196 & 0.506 & 0.784 & -0.032 & -0.364 & -0.200 \\
\hline DMAR & 0.196 & 0.506 & 0.784 & -0.032 & -0.364 & -0.200 \\
\hline
\end{tabular}

Values followed by (*) and (**) show correlation at $\mathrm{p}<0.05$ and 0.01 , respectively. 
According to Raij et al. (2011), excess P does not affect plant growth. Malavolta (2006) reported that direct symptoms of $\mathrm{P}$ excess are not recognized, but there may be micronutrient deficiency, especially heavy metals such as $\mathrm{Cu}, \mathrm{Fe}$, $\mathrm{Mn}$ and $\mathrm{Zn}$. The same authors noted that the hidden excess of nutrients can cause reduced growth and production without visible symptoms, as in this work in which a negative correlation was observed with the production of green mass.

Although $\mathrm{N}$ is one of the nutrients most absorbed by the forages, no significant correlation was observed with productivity for the four forages studied. According to Garcez Neto el al. (2002), productivity can be stimulated through the supply of $\mathrm{N}$ and to vary in terms of the dose and species used.

This non-significant correlation between $\mathrm{N}$ and productivity may be due to application of the recommended dose instead of different doses as reported in other studies. Andrade et al. (2003) researching different doses of $\mathrm{N}$ and reported linear increases in production with nitrogen fertilization.

Regarding micronutrients, there was a significant negative correlation for Fe in the Xaraés forage, $\mathrm{p}<0.01$ between Fe and TGM, and $\mathrm{p}<0.05$ between the same micronutrient and TDM and DMAR (Table 6).

Table 6. Simple linear correlation matrix between micronutrients (B, $\mathrm{Cu}, \mathrm{Fe}, \mathrm{Mn}$ and $\mathrm{Zn}$ ) and total green mass (TGM), total dry matter (TDM) and dry mass accumulation rate (DMAR) for irrigated forages.

\begin{tabular}{|c|c|c|c|c|c|}
\hline \multicolumn{6}{|c|}{ Napier } \\
\hline & B & $\mathbf{C u}$ & $\mathbf{F e}$ & Mn & $\mathbf{Z n}$ \\
\hline TGM & 0.681 & 0.086 & -0.078 & 0.075 & -0.638 \\
\hline TDM & 0.744 & 0.020 & 0.558 & 0.048 & -0.242 \\
\hline DMAR & 0.744 & 0.020 & 0.558 & 0.048 & -0.242 \\
\hline \multicolumn{6}{|c|}{ Mombasa } \\
\hline & B & $\mathbf{C u}$ & $\mathbf{F e}$ & Mn & $\mathbf{Z n}$ \\
\hline TGM & -0.206 & -0.817 & -0.097 & -0.058 & -0.270 \\
\hline TDM & -0.316 & -0.742 & 0.202 & -0.152 & -0.088 \\
\hline DMAR & -0.316 & -0.742 & 0.202 & -0.152 & -0.088 \\
\hline \multicolumn{6}{|c|}{ Xaraés } \\
\hline & B & $\mathbf{C u}$ & $\mathbf{F e}$ & Mn & $\mathbf{Z n}$ \\
\hline TGM & -0.851 & -0.832 & $-0.978 * *$ & 0.067 & -0.765 \\
\hline TDM & -0.849 & -0.759 & $-0.952 *$ & 0.217 & -0.700 \\
\hline DMAR & -0.849 & -0.759 & $-0.952 *$ & 0.217 & -0.700 \\
\hline \multicolumn{6}{|c|}{ Ruziziensis } \\
\hline & B & $\mathrm{Cu}$ & $\mathbf{F e}$ & Mn & $\mathbf{Z n}$ \\
\hline TGM & -0.319 & 0.545 & -0.497 & 0.142 & 0.236 \\
\hline TDM & -0.462 & 0.298 & -0.513 & 0.125 & 0.057 \\
\hline DMAR & -0.462 & 0.298 & -0.513 & 0.125 & 0.057 \\
\hline
\end{tabular}

Values followed by $(*)$ and $(* *)$ show correlation $\mathrm{p}<0.05$ and 0.01 respectively.

Gontijo et al. (2012), when evaluating the productivity of another crop also observed a significant negative correlation between the $\mathrm{Fe}$ content in the soil and productivity, attributing this effect to the high content of this element in the soil, as observed in the present study. The same authors reported that excess $\mathrm{Fe}$ promotes its excessive absorption, causing nutritional imbalance which can lead to production losses.

The high Fe content may be associated with the soil source material, because high Fe levels are common in soils of the region. Gontijo et al. (2012) also attribute the high $\mathrm{Fe}$ content observed to the source material and complemented that this $\mathrm{Fe}$ concentration causes the gradual loss by lixiviation of other elements.
A similar result for $\mathrm{N}$ was observed for $\mathrm{Mn}$, which although it was one of the most absorbed nutrients showed no significant correlation. Mingotte et al. (2011) studied different doses of Mn and observed that the application of Mn increased dry mass production. Another fact that may have contributed is the high content of this micronutrient in the soil, exceeding the adequate range.

Kliemann et al (2003) reviewed the relationship between nutrients and the production of green mass from Urochloa brizantha. They found no relationship between the $\mathrm{Fe}$ and $\mathrm{Mn}$ contents available in the soil and the production of green mass from Urochloa brizantha, in agreement with the results obtained in this work. 
It was observed that nutrient contents correlated better with each other than with forage productivity (Table 7). For each forage studied there was a different behavior among the nutrients, verifying the influence of the species on nutrient availability.

Table 7. Simple linear correlation matrix between nutrients for irrigated forages.

\begin{tabular}{|c|c|c|c|c|c|c|c|c|c|c|c|}
\hline \multicolumn{12}{|c|}{ Napier } \\
\hline & $\mathbf{N}$ & $\mathbf{P}$ & $\mathbf{K}$ & $\mathbf{C a}$ & Mg & $\mathbf{S}$ & B & $\overline{\mathbf{C u}}$ & $\mathbf{F e}$ & Mn & $\overline{Z n}$ \\
\hline $\mathbf{N}$ & - & $\begin{array}{l}- \\
0.2267\end{array}$ & $\begin{array}{l}- \\
0.9671 * *\end{array}$ & 0.0998 & 0.7195 & 0.3765 & 0.2572 & $-\overline{0.5315}$ & $0.8898 *$ & 0.7690 & 0.3757 \\
\hline $\mathbf{P}$ & & - & -0.0133 & $-\overline{0.6734}$ & $-\overline{0.0896}$ & 0.3760 & -0.6434 & $-\overline{0.2575}$ & -0.0399 & -0.0165 & 0.6963 \\
\hline $\mathbf{K}$ & & & - & 0.0600 & $\begin{array}{l}- \\
0.7096\end{array}$ & 0.5099 & -0.1401 & 0.6538 & $-\overline{0.9109 *}$ & -0.8276 & -0.5776 \\
\hline $\mathbf{C a}$ & & & & - & 0.5268 & 0.2520 & $0.9156^{*}$ & 0.5753 & 0.2820 & 0.2378 & -0.2067 \\
\hline Mg & & & & & 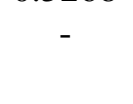 & 0.7727 & 0.5640 & $\begin{array}{l}- \\
0.0227\end{array}$ & $0.9274 *$ & 0.7755 & 0.5826 \\
\hline $\mathbf{S}$ & & & & & & 年 & 0.4135 & 0.2144 & 0.7454 & 0.7988 & $0.8887 *$ \\
\hline B & & & & & & & - & 0.2222 & 0.4396 & 0.5250 & -0.0348 \\
\hline $\mathbf{C u}$ & & & & & & & & - & -0.3881 & -0.5692 & -0.4487 \\
\hline $\mathbf{F e}$ & & & & & & & & & - & $0.9128^{*}$ & 0.6555 \\
\hline Mn & & & & & & & & & & - & 0.6841 \\
\hline $\mathbf{Z n}$ & & & & & & & & & & & - \\
\hline \multicolumn{12}{|c|}{ Mombasa } \\
\hline & $\mathbf{N}$ & $\mathbf{P}$ & $\mathbf{K}$ & $\mathbf{C a}$ & Mg & $\mathbf{S}$ & B & $\mathbf{C u}$ & $\mathbf{F e}$ & Mn & $\mathbf{Z n}$ \\
\hline $\mathbf{N}$ & - & 0.2386 & -0.4304 & $-\overline{0.1304}$ & 0.0305 & 0.1300 & 0.1897 & -0.5826 & 0.6252 & -0.0421 & -0.6052 \\
\hline $\mathbf{P}$ & & - & -0.2495 & $-\overline{0.1364}$ & $-\overline{0.7699}$ & $-\overline{0.1078}$ & 0.0890 & 0.0101 & 0.2468 & -0.6494 & -0.1714 \\
\hline $\mathbf{K}$ & & & - & 0.5334 & 0.7821 & 0.0680 & -0.0925 & 0.2174 & $\begin{array}{l}- \\
0.0399\end{array}$ & -0.3325 & -0.0453 \\
\hline $\mathbf{C a}$ & & & & - & 0.4144 & - & 0.7884 & 0.7159 & $\begin{array}{l}- \\
0.6877\end{array}$ & -0.3446 & -0.5535 \\
\hline Mg & & & & & - & 0.0674 & -0.1047 & 0.0000 & 0.2792 & 0.0900 & -0.0631 \\
\hline $\mathbf{S}$ & & & & & & - & $-0.9470 *$ & -0.8459 & 0.6182 & 0.2075 & 0.4807 \\
\hline B & & & & & & & - & 0.6390 & - & -0.2579 & -0.6841 \\
\hline $\mathbf{C u}$ & & & & & & & & - & 0.1737 & 0.0861 & 0.0365 \\
\hline $\mathbf{F e}$ & & & & & & & & & - & 0.2839 & 0.8753 \\
\hline $\begin{array}{c}\mathrm{Mn} \\
\mathrm{Zn}\end{array}$ & & & & & & & & & & - & $\begin{array}{c}0.6810 \\
-\end{array}$ \\
\hline \multicolumn{12}{|c|}{ Xaraés } \\
\hline & $\mathbf{N}$ & $\mathbf{P}$ & $\mathbf{K}$ & $\mathbf{C a}$ & Mg & $\mathbf{S}$ & B & $\mathrm{Cu}$ & $\mathbf{F e}$ & Mn & $\mathbf{Z n}$ \\
\hline $\mathbf{N}$ & - & $-\overline{0.0426}$ & -0.4860 & $-\overline{0.0710}$ & -0.0221 & $-\overline{0.4060}$ & -0.0440 & -0.0128 & $-\overline{0.1396}$ & 0.8111 & 0.2316 \\
\hline $\mathbf{P}$ & & - & 0.6100 & 0.7756 & 0.7337 & 0.5717 & 0.4333 & 0.3885 & 0.8416 & -0.2877 & $0.9304 *$ \\
\hline $\mathbf{K}$ & & & - & 0.5853 & 0.8077 & 0.4104 & -0.1838 & -0.3330 & 0.2244 & -0.8495 & 0.3101 \\
\hline $\mathbf{C a}$ & & & & - & 0.4204 & 0.1368 & -0.1050 & 0.3370 & 0.5250 & -0.1821 & 0.5981 \\
\hline
\end{tabular}




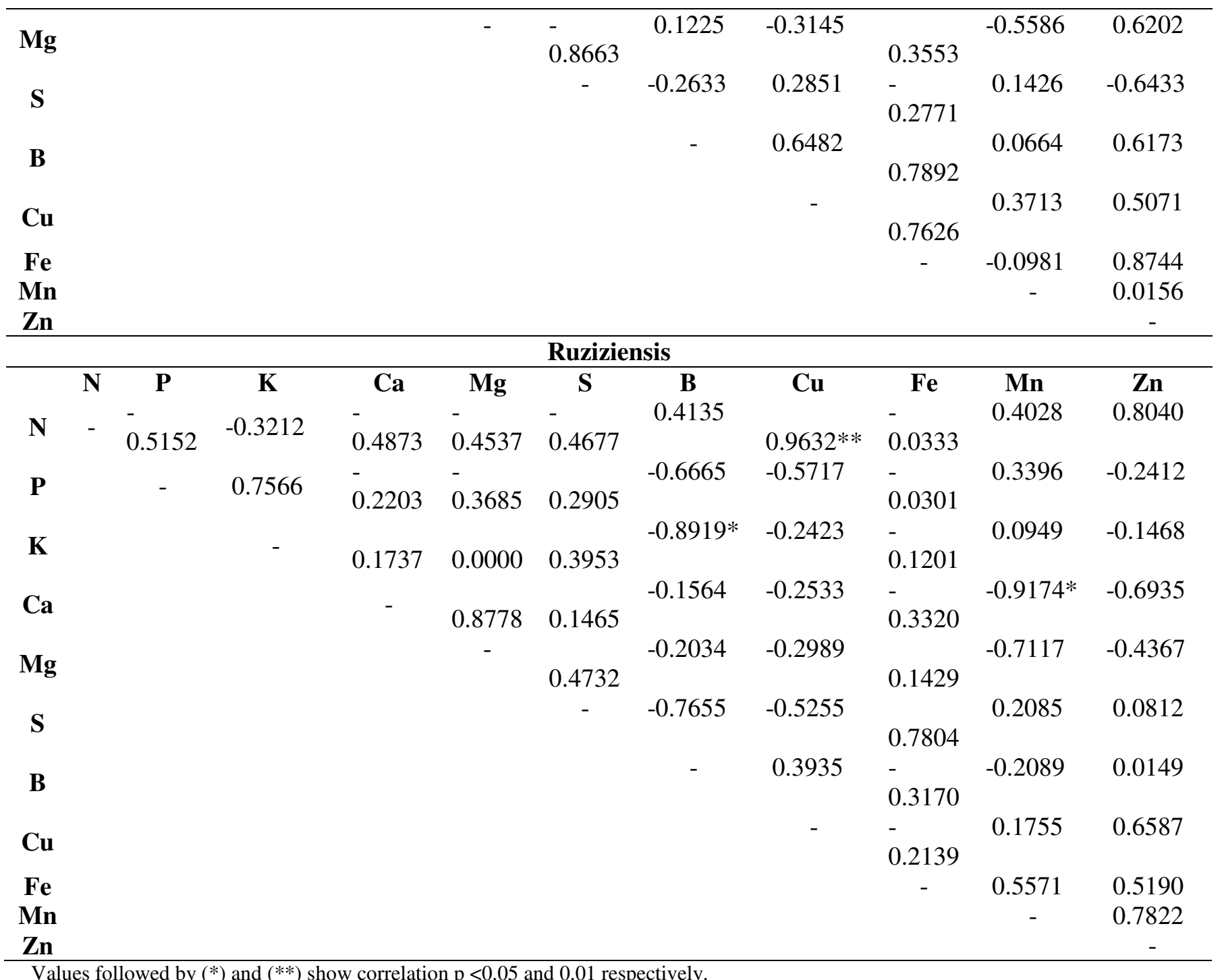

The Napier and Ruziziensis forages provided more correlations between nutrients. Most correlations for the Napier forage where with the micronutrient $\mathrm{Fe}$, which presented positive correlation with $\mathrm{N}$ and $\mathrm{Mg}$, and negative correlation with $\mathrm{K}$, both at $\mathrm{p}<0.05$. According to Malavolta (2006), one of the functions of $\mathrm{Fe}$ is the assimilation of $\mathrm{N}$ in the plants, which explains this positive correlation between the two elements.

In regards to correlations between $\mathrm{Fe}$ with $\mathrm{Mg}$ and K, Malavolta (2006) reported that excess Fe causes lower absorption of $\mathrm{K}, \mathrm{Ca}$ and $\mathrm{Mg}$, but there is genetic diversity in the tolerance to toxicity. According to the authors, depending on the concentration of the element there may be synergism or inhibition. It is observed that $\mathrm{Fe}$ caused a lower absorption of $\mathrm{K}$, confirming the hypothesis of inhibition, but synergism with $\mathrm{Mg}$.

Potassium presented a negative correlation $\mathrm{p}$ $<0.01$ with N. Primavesi et al. (2006) observed that $\mathrm{K}$ increases the efficiency of $\mathrm{N}$ use, and they also emphasize that the contents of $\mathrm{K}$ in the plant increased with the doses of $\mathrm{N}$, which was not observed in this work.

The preferential forms of $\mathrm{N}$ to be absorbed by plants are ammonia $\left(\mathrm{NH}^{+4}\right)$ and nitrate $\left(\mathrm{NO}^{-3}\right)$ (Malavolta, 2006), which might have caused this negative correlation between $\mathrm{K}$ when $\mathrm{N}$ is absorbed in the form of ammonia. Andrade et al. (2000) evaluated productivity of the forage Napier and also observed that the $\mathrm{K}$ levels decreased with nitrogen fertilization, i.e., it can be concluded that this negative correlation between the two nutrients may be characteristic of the forage species.

$\mathrm{Mn}$ presented a positive correlation with $\mathrm{Fe}$ and $\mathrm{Zn}$ with $\mathrm{S}$, both at $\mathrm{p}<0.05$. With respect to the positive correlation between $\mathrm{Zn}$ and $\mathrm{S}$, this may have occurred because the accompanying ion of the sulfate is $\mathrm{Zn}$, thus providing its absorption. Regarding the correlation between $\mathrm{Mn}$ and $\mathrm{Fe}$, according to Malavolta (2006) excess $\mathrm{Fe}$ may induce Mn deficiency, a fact not observed in this 
work. The positive correlation between $\mathrm{Mn}$ and $\mathrm{Fe}$ may have occurred due to the high content of the two elements, since they are above the appropriate range.

For the Mombasa forage, a negative correlation was found between S and B $(p<0.05)$. This negative correlation may be due to competition for the same exchange site, since the absorbed form of both are anions according to Malavolta (2006), where $\mathrm{S}$ is absorbed mainly as $\mathrm{SO}_{4}^{-2}$ and $\mathrm{B}$ as $\mathrm{BO}_{3}{ }^{-2}$.

There was a positive correlation $(\mathrm{p}<0.05)$ between $\mathrm{P}$ and $\mathrm{Zn}$ for Xaraés. On the other hand, according to Raij (2011) the phosphates tend to reduce the solubility of $\mathrm{Zn}$, where deficiencies induced of the element by high phosphate fertilizations and known. This is due to the accompanying cation of the phosphate source to inhibit absorption of $\mathrm{Zn}$. This did not occur for the Xaraés forage, which even with high P levels in the soil and plant showed a positive correlation between the two elements.

In the Ruziziensis forage, a positive correlation was observed $(\mathrm{p}<0.01)$ between $\mathrm{N}$ and $\mathrm{Cu}$, and negative $(\mathrm{p}<0.05)$ between $\mathrm{K}$ and $\mathrm{B}$, and $\mathrm{Ca}$ and $\mathrm{Mn}$. This negative correlation between $\mathrm{Ca}$ and $\mathrm{Mn}$ is due to competition for the same exchange site. Malavolta (2006) reported that absorption of
$\mathrm{Mn}$ is reduced by the presence of bivalent cations such as $\mathrm{Ca}^{+2}$ and $\mathrm{Zn}^{+2}$. There are no reports of negative correlation between $\mathrm{B}$ and $\mathrm{K}$, but this may have occurred because the accompanying cation of $\mathrm{B}$ inhibits the $\mathrm{K}$ absorption.

In relation to the positive correlation between $\mathrm{Cu}$ and $\mathrm{N}$, Primavesi et al. (2006) and Andrade et al. (1996) observed that $\mathrm{Cu}$ contents increased with the doses of $\mathrm{N}$. According to Loneragan (1981) this is because $\mathrm{Cu}$ has a strong affinity for the $\mathrm{N}$ atom of the amino group; additionally soluble nitrogen compounds, such as amino acids, act as chargers of this nutrient.

\section{CONCLUSIONS}

Irrigation results in higher levels of the macronutrients $\mathrm{P}, \mathrm{K}$ and $\mathrm{Mg}$ and the micronutrients $\mathrm{Fe}$ and $\mathrm{Mn}$ in forages.

The nutrients that correlated with productivity were $\mathrm{P}$ and $\mathrm{Fe}$, both of which presented negative correlation. Phosphorus showed a negative correlation with the total green mass in the Napier forage, and $\mathrm{Fe}$ with the total green mass, total dry mass and accumulation rate in Xaraés forage.

The nutrients correlated better with each other than with forage productivity.

RESUMO: A irregularidade do regime pluviométrico pode tornar-se uma restrição ao desenvolvimento das culturas, de maneira que a irrigação de pastagens serve como estratégia para a intensificação dos sistemas de produção animal a pasto. Devido a relação direta entre a disponibilidade de água no solo e os nutrientes, objetivou-se avaliar os teores dos nutrientes em forrageiras irrigadas por pivô central. $\mathrm{O}$ trabalho foi realizado na área experimental de agricultura irrigada da Universidade Estadual de Mato Grosso do Sul, em Aquidauana-MS. Adotou-se o delineamento inteiramente casualizado, com cinco repetições, em parcelas subdivididas. Os tratamentos das parcelas foram, irrigado e não irrigado, e os tratamentos das subparcelas, foram as forrageiras Urochloa brizantha cv. Xaraés, Pennisetum purpureum cv. Napier, Panicum maximum cv. Mombaça e Urochloa ruziziensis cv. Ruziziensis. Foram avaliadas as concentrações foliares dos nutrientes Nitrogênio (N), Fósforo (P), Potássio (K), Cálcio $(\mathrm{Ca})$, Magnésio $(\mathrm{Mg})$, Enxofre (S), Cobre $(\mathrm{Cu})$, Ferro (Fe), Manganês (Mn) e Zinco ( $\mathrm{Zn})$. Foi realizada a análise de variância, teste Tukey $\mathrm{p}<0,05$ e matriz de correlação linear $\mathrm{p}<0,05$ e $\mathrm{p}<0,01$ entre os nutrientes e a produtividade. A irrigação propicia maiores teores dos macronutrientes $\mathrm{P}, \mathrm{K}$ e $\mathrm{Mg}$ e dos micronutrientes $\mathrm{Fe}$ e $\mathrm{Mn}$ nas forrageiras. Os teores de nutrientes que correlacionaram com a produtividade foram o $\mathrm{P}$ e o Fe, ambos apresentaram correlação negativa. Os teores de nutrientes correlacionaram melhor entre si do que com a produtividade das forrageiras.

PALAVRAS-CHAVE: Pastagem irrigada. Pivô central. Nutrição de forrageiras.

\section{REFERENCES}

ALENCAR, C. A. B.; OLIVEIRA, R. A.; CÓSER, A. C.; MARTINS, C. E.; CUNHA, F. F.; FIGUEIREDO, J. L. A.; CECON, P. R.; LEAL, B. G. Valor nutritivo de gramíneas forrageiras tropicais irrigadas em diferentes épocas do ano. Pesquisa Agropecuária Tropical, v. 40, n. 1, p. 20-27, 2010.

https://doi.org/10.5216/pat.v40i1.3994 
ALLEN, R. G.; PEREIRA, L. S.; RAES, D.; SMITH, M. Pan evaporation method. In: Crop evapotranspiration: guidelines for computing crop requirements. Roma: FAO, 1998. p. 78-85.

ANDRADE, A. C.; FONSECA, D. M.; QUEIROZ, D. S.; SALGADO, L. T.; CECON, P. R. Adubação nitrogenada e potássica em capim-elefante (Pennisetum purpureum Schum. cv. Napier). Ciência Agrotécnica, edição especial, p. 1643-1651, 2003. https://www.researchgate.net/publication/228754609

ANDRADE, A. C.; FONSECA, D. M.; GOMIDE, J. A.; ALVAREZ, V. H.; MARTINS, C. E.; SOUZA, D. P. H. Produtividade e valor nutritivo do capim-elefante cv. Napier sob doses crescente de nitrogênio e potássio. Revista Brasileira de Zootecnia, v. 29, n. 6, p. 1589-1595, 2000. https://doi.org/10.1590/S151635982000000600001

AVEIRO, A. R.; SIEWERDT, L.; SILVEIRA, J. R. Capim-elefante: efeito da irrigação e das adubações mineral e orgânica. III - produção total de matéria verde e sua distribuição sazonal. Revista Brasileira de Zootecnia, v. 20, n. 4, p. 356-364, 1991.

BERNARDO, S; SOARES, A. A.; MANTOVANI, E. C. Manual de irrigação. 8.ed. Viçosa: Editora UFV, 2007. 625p.

Centro de Estudos Avançados em Economia Aplicada (CEPEA) - ESALQ/USP. 2016. PIB do Agronegócio Brasileiro - Relatório Completo 2016. Available at: www.cepea.com.br. Accessed on February 10, 2018.

COSTA, K. A. P.; OLIVEIRA, I. P.; SEVERIANO, E. C.; SAMPAIO, F. M. T.; CORRIJO, M. S.; RODRIGUES, C. R. Extração de nutrientes pela fitomassa de cultivares de Brachiaria Brizantha sob doses de nitrogênio. Ciência Animal Brasileira, v. 11, n. 2, p. 307-314, 2010. https://doi.org/10.5216/cab.v11i2.4043

Embrapa, 2001. Exigências nutricionais das forrageiras. In: Interações entre a adubação de pastagens e a suplementação mineral de bovinos. Embrapa Gado de Corte, Campo Grande, MS.

GARCEZ NETO, A. F.; NASCIMENTO JÚNIOR, D.; REGAZZI, A. J.; FONSECA, D. M.; MOSQUIM, P. R.; GOBBI, K. F. Respostas morfogênicas e estruturais de Panicum maximum cv. Mombaça sob diferentes níveis de adubação nitrogenada e alturas de corte. Revista Brasileira de Zootecnia, v. 31, p. 1890-1900, 2002. https://doi.org/10.1590/S1516-35982002000800004

GONTIJO, I.; NICOLE, L. R.; PARTELLI, F. L.; BONOMO, R.; SANTOS, E. O. J. Variabilidade e correlação espacial de micronutrientes e matéria orgânica do solo com a produtividade da pimenta do reino. Revista

Brasileira de Ciência do Solo, v. 36, p. 1093-1102, 2012. https://doi.org/10.1590/S0100-06832012000400004

Instituto Brasileiro de Geografia e Estatística (IBGE), 2015. Produção da pecuária municipal 2015.IBGE, Rio de Janeiro, RJ, v. 43, p. 1-49.

KLIEMANN, H. J.; MAGALHÃES, R. T.; OLIVEIRA, I. P.; MORAES, M. F. Relações da produção de massa verde de Brachiaria brizantha com os índices de disponibilidade de nutrientes em solos sob sistema barreirão de manejo. Pesquisa Agropecuária Tropical, v. 33, n. 1, p. 49-56, 2003.

https://doi.org/10.5216/pat.v33i1.2400

KRAESKI, M. J. Micronutrientes em gramíneas forrageiras irrigadas, em Aquidauana-MS. 2016. 16p. Tese de conclusão de curso (Graduação em Agronomia) - Universidade Estadual de Mato Grosso do Sul, AquidauanaMS, 2016.

LOPES, A. S. Micronutrientes: Filosofias de aplicação e eficiência agronômica. São Paulo: ANDA, 1999. 69p.

LORENAGAN, J. F. Distribution and movement of copper in plants. In: LONERAGAN, J. F.; ROBSON A.

D.; GRAHAM, R. D. Copper in soils and plants. Sydney: Academic Press, 1981. p. 165-188. 
MALAVOLTA, E.; VITTI, G. C.; OLIVEIRA, S. A. Avaliação do estado nutricional das plantas: princípios e aplicações. 2.ed. Piracicaba: Potafos, 1997. 319p.

MALAVOLTA, E. Manual de nutrição mineral de plantas. São Paulo: Editora Agronômica Ceres, 2006. 638p.

Ministério da Agricultura, Pecuária e Abastecimento (MAPA), 2016. Exportação. MAPA, Brasília, DF.

MINGOTTE, F. L. C.; SANTOS, C. L. R.; PRADO, R. M.; FLORES, R. A.; TOGORO, A. H.; SILVA, J. A. S.; POLITI, L. S.; PINTO, A. S.; AQUINO, D. S. Manganês na nutrição e na produção de massa seca do capim-mombaça. Bioscience Journal, v. 27, n. 6, p. 879-887, 2011.

http://www.seer.ufu.br/index.php/biosciencejournal/article/view/11721

MISTURA, C.; FAGUNDES, J. L.; FONSECA, D. M.; MOREIRA, L. M.; VITOR, C. M. T.; NASCIMENTO JÚNIOR, D.; RIBEIRO JÚNIOR, J. I. Disponibilidade e qualidade do capim-elefante com e sem irrigação adubado com nitrogênio e potássio na estação seca. Revista Brasileira de Zootecnia, v. 35, n. 2, p. 372-379, 2006. https://doi.org/10.1590/S151635982006000200006

OLIVEIRA, P. P. A.; SOUZA, F. H. D.; LUZ, P. H. C.; HERLING, V. R. Avaliação da adubação com micronutrientes em pastagens sob irrigação para a produção de forragem e de sementes. São Carlos:

EMBRAPA, 2006. 40p. (Boletim de Pesquisa e Desenvolvimento, 8).

PIRES, W. Manual de pastagem. Viçosa: Aprenda Fácil, 2006. 302p.

POTT, E. B.; ALMEIDA, I. L.; BRUM, P. A. R.; COMASTRI FILHO, J. A.; POTT, A.; DYNIA, J. F. Nutrição mineral de bovinos de corte do pantanal mato grossense: 2. Micronutrientes na Nhecolândia (Parte Central). Pesquisa Agropecuária Brasileira, v. 24, n. 1, p. 109-126, 1989.

https://seer.sct.embrapa.br/index.php/pab/article/viewFile/13818/7842

PRIMAVESI, A. C.; PRIMAVESI, O.; CORRÊA, L. A.; SILVA, A. G.; CANTARELLA, H. Nutrientes na fitomassa de capim-marandu em função de fontes e doses de nitrogênio. Ciência Agrotécnica, v. 30, n. 3, p. 562-568, 2006. https://doi.org/10.1590/S1413-70542006000300024

RAIJ, B. V.; ANDRADE, J. C.; CANTARELLA, H.; QUAGGIO, J. A. Análise Química para avaliação da fertilidade de solos tropicais. Campinas: Instituto Agronômico, 2001. 285p.

RAIJ, B. V. Fertilidade do solo e manejo de nutrientes. Piracicaba: IPNI, 2011. 420p.

SCHIAVO, J. A.; PEREIRA M. G.; MIRANDA, L. P. M.; DIAS NETO, A. H.; FONTANA, A. Caracterização e classificação de solos desenvolvidos de arenitos da formação Aquidauana-MS. Revista Brasileira de Ciência do Solo, v. 34, p. 881-889, 2010. https://doi.org/10.1590/S0100-06832010000300029

SOUSA, D. M. G.; LOBATO, E. Cerrado: correção do solo e adubação. 2.ed. Brasília: Embrapa Informação Tecnológica, 2004. 416p. 